\title{
SURVEY OF NEWLY BORN CALVES MANAGEMENT PRACTICE IN NEW VALLEY GOVERNORATE
}

\author{
NORA ABD ELBAETH S. MOHAMED ${ }^{1}$; MOATAZ A. M. ABDEL-RAHMAN ${ }^{2}$; \\ SOTOHY A. SOTOHY ${ }^{3}$ AND RAMADAN D. EL SHOUKARY \\ ${ }^{1}$ Department of Animal Hygiene, Faculty of Veterinary Medicine, New Valley University \\ ${ }^{2}$ Department of Behavior and Management of Animal Wealth, Dean of Faculty Veterinary Medicine - \\ Minia University, 71526, Egypt. \\ ${ }^{3}$ Department of Animal Hygiene, Faculty of Veterinary Medicine, Assiut University, 72511, Egypt
}

Received: 27 December 2020; Accepted: 8 February 2021

\begin{abstract}
The objective of this work was to conduct a broad survey of newly born calves management practices that have an effect on animal behavior and mortality. Animal's farms were visited during the summer of 2019 in new valley government. Data were collected on 70 farms to answer the questions about Calving pen presence, calves raising method, colostrum feeding number or volume, mortality rate, care of newly born animal, weaning age and method used. The obtained data showed that, $85 \%$ of Calves were raised by the owner till fatting and $13 \%$ were pursued from the market, A total of $95 \%$ of owners haven't calving pen in thier frame beside that, $73 \%$ of them were fed all colostrum during 6 hours after parturition and $60 \%$ of them were feed colostrum two days. On the other hand, $67 \%$ of owners did not used disinfectant after parturition which associated with $22 \%$ mortality rate of newly born calves. Finally data obtained show that, about $75 \%$ of owners were weaned the animal more than 4 month with gradually weaning type.
\end{abstract}

Keywords: Newly born calve management, weaning method, calf rearing.

\section{INTRODUCTION}

There is increasing societal concern about the newly born animals management to enable the farming industry to effectively respond to these concerns, there is a need for more in-depth data on management practices that are actually being used, (Fulwider et al., 2008). The

Corresponding author: Nora Abd ElbaethS.Mohamed E-mail address: norabaeth@gmail.com

Present address: Department of Animal Hygiene, Faculty of Veterinary Medicine, New Valley University conditions at calving represent a major hazard for the health of the newborn calf. Calving requires special facilities (such as a calving pen) designed to minimize stress and ensure the comfort and hygiene of the cow and newborn calf. Moreover, housing management of calves pen, area per calf, number of calve per pen; adequate and well-balanced diet (colostrum, milk, and calf starter), and social contact can influence their lying behavior, feeding status, and social behavior with negative effects on their growth and development, because to maintain body integrity while growing, calves need: movement and exercise space for bone and muscle 
development (Algers et al., 2006), beside that, the housing of dairy calves can be done individually, in pairs or groups. De Paula Vieira et al. (2010), benefits attributed to paired and group-housing are reduced labor requirements per calf; improved social behavior of calves (Duve and Jensen, 2012), higher intakes of starter feed and gains (De Paula Vieira et al., 2010). The data about newly born animal management in New valley governate are limited so that, the objective of our study was to survey a larger number of farm and determine the newly born calve management point and its effect on their health status or mortality rate.

\section{MATERIALS AND METHODS}

In total, 70 animal farms located in New Valley governate \{Mut (20), AL-Maasara (5), Asmant (3), Al-Gadida (2), Al-Eweina (3), AL-sheikh Wali (8), AL-Hendaw (2), in AL-Rashda (3), El kharga (17), Sanaa (4), paris (1) and Polaq (2)\} were assessed in the summer periods 2019. Some of these farms were of single type animals (male or female or mixed) while others were of mixed type animals (sheep and cattle). Farm number was in line with Espejo and Endres (2007) who visited 50 dairies in Minnesota and Cook et al. (2004) and Schreiner and Ruegg (2002) who conducted field studies on 12 and 8 dairies, respectively, in Wisconsin.

In order to Assess Newly born animals managemental point which done by the owner and its effect on calves behavior and health, some questions were asked which contain different points as calving pen (single calve pen), but (grouped calve pen) are not present.

Calve raising method., new born animal perished, still in the farm to fattening, not determined, (Die of newly born animals) die within 3 month(without calving pen), die within 3 month (with calving pen), not die within 3 month, colostrum (all colstrum (first 6 hour), all colstrum (normal with its mother), take part of it), Weaning age (1-2 month), (2-4 month), more), weaning type was (complete, incomplete, gradual) while, First feed by itself(1-2 weeks alone), (3-5w alone), (1$3 \mathrm{w}$ with other), Forced feeding (yes $<15$, yes $>15$, no), if the mother die (foster mother, milk replacer ), First time access to feeding $(<1$ weeks, >1weeks, not determined) and First time access water ( $<1$ weeks, $>1$ weeks) All questionnaires were individually examined and the data were recorded in (Microsoft Excel 2010) to get the percentage of each parameter. 


\section{RESULT}

Table 1: Managemental point done by owner in his farm which obtained from survey.

\begin{tabular}{|c|c|}
\hline Calving pen & \\
\hline Present (single calve pen) & $2 \%$ \\
\hline Present (grouped calve pen) & $3 \%$ \\
\hline Not present & $95 \%$ \\
\hline Calf-Raising Method & \\
\hline new born animal perished & $13.0 \%$ \\
\hline still in the farm to fattening & $85.0 \%$ \\
\hline not determined & $2.0 \%$ \\
\hline Colostrum feeding volume & \\
\hline All colostrum (first 6 hour) & $73 \%$ \\
\hline All colostrum (normal with its mother) & $9 \%$ \\
\hline Take part of it & $18 \%$ \\
\hline Colostrum feeding number & \\
\hline One feeding per day & $24 \%$ \\
\hline Two feeding per day & $60 \%$ \\
\hline Ad-libtum & $16 \%$ \\
\hline Die of newly born animals & \\
\hline Die within 3 month ( without calving pen) & $20 \%$ \\
\hline Die within 3 month ( with calving pen) & 2 \\
\hline Not die within 3 month & $78 \%$ \\
\hline Disinfection after birth (care of newly born & \\
\hline Used disinfection (antibiotic or iodine) & $23 \%$ \\
\hline Not used & $67 \%$ \\
\hline Weaning Age & \\
\hline $1-2$ month & $1 \%$ \\
\hline 2-4 month & $22 \%$ \\
\hline More & $77 \%$ \\
\hline Weaning type & \\
\hline complete & $2 \%$ \\
\hline incomplete & $23 \%$ \\
\hline Gradual & $75 \%$ \\
\hline first time access to feeding & \\
\hline$<1$ weeks & $93 \%$ \\
\hline$>1$ weeks & $5 \%$ \\
\hline not determint & $2 \%$ \\
\hline First time access water & \\
\hline$<1$ weeks & $90 \%$ \\
\hline$>1$ weeks & $8 \%$ \\
\hline not determint & $2 \%$ \\
\hline
\end{tabular}




\section{DISCUSSION}

\section{1- Calf-Raising Method}

$85 \%$ of the owners raised their own calves from birth to entry into fattening cycle, while, $13 \%$ of owners purished it, this data in accordance with previous finding of. Fulwider et al. (2007) who mentioned that, half of the dairies raised their own heifer calves from birth to entry into the milking herd $(50.4 \%)$.

\section{2- Colostrum Feeding}

Colostrum management remains one of the most serious hazards for calf welfare (European Food Safety Authority, 2006). In the current survey there was $82 \%$ of calves were fed colostrum as whole volume and given it within 6 hours after parturition by the owner or left the calve with its dam to take it, while $18 \%$ from the owners was take apart of this colostrum and spread to the neighbor as a gift. (Table1), this data agreed with finding of Fulwider et al. (2007) who find that, Colostrum was fed to calves on $94.7 \%$ of dairies.

More over, $76 \%$ of producers who raised their own calves provided more than 1 feeding of colostrum per day while, $24 \%$ of owner feed it one per day. In contrary, Hopkins and Quigley (1997) reported that calves fed $3.8 \mathrm{~L}$ of colostrum in 1 or 2 feedings were equally effective in providing passive immunity. The mean colostrum consumption for calves fed colostrum once and to appetite was $3.0 \mathrm{~L}$, or $8 \%$ of $\mathrm{BW}$. Calves fed 2 or $2+$ times in $24 \mathrm{~h}$ consumed 3.2 and $3.3 \mathrm{~L}$, respectively. Jaster (2005) found that Jersey calves provided with 2 colostrum feedings of $2 \mathrm{~L}$ at 0 and $12 \mathrm{~h}$ had higher IgG1 than calves fed $4 \mathrm{~L}$ at birth.

Data puplished on this topic about timing of colostrum feeding was in agreement with data of Weaver et al. (2000) who reported that, the timing of the first meal of colostrum is critical because optimal absorption of immunoglobulins occurs before $4 \mathrm{~h}$ of age and decreases rapidly after $12 \mathrm{~h}$. and Kehoe et al. (2007) stated that, it is likely that many calves received their first hand-fed colostrum more than $6 \mathrm{~h}$ after birth. These results are similar to those of a recent United States survey that reports that $43.6 \%$ of farms feed calves colostrum within $2 \mathrm{~h}$ after birth, and $51 \%$ feed colostrum between 2 and $6 \mathrm{~h}$ after birth. Beside that, in the herds surveyed in our study, colostrum from primiparous cows was used in $94.7 \%$, which is slightly higher than in United States dairy herds. Franklin et al. (2003) reported that, Calves that get colostrum only during nursing may not receive a proper quality or amount of colostrum in a timely manner, which increases risks of failure of passive transfer., National Farm Animal Care Council, (2009) mentiond that, the calf receives its first colostrum feeding no more than $6 \mathrm{~h}$ after birth. And In 36.8\% of herds surveyed, the disinfection of the newborn's navel was not done despite recommendations.

\section{3- Feed and water accesses}

Obtained data showed that, about $93 \%$ and $90 \%$ of survey farm get access to feed and water to its calve less than one week age and it was agreed with of Kertz et al. (1984) who found that, Free water intake is essential for proper rumen function and for early intake of dry feed and should therefore be made available within the first week of life. Also, USDA, (2008) found that, in the herds surveyed, calves had access to concentrate at a median age of 7 day after birth and the median amount offered was $1 \mathrm{~kg}$. In the United States, average age for grain access is similar to Quebec herds (8.5 days) about $9.6 \%$ of farms reported not giving unweaned calves' access to water.

\section{4- Calving pen and calf mortality}

The conditions at calving represent a major hazard for the health of the newborn calf. Calving requires special facilities (such as a calving pen) designed to minimize stress and ensure the comfort and hygiene of the cow and newborn calf. (USDA, 2008). 


\subsection{Calving pen}

Data illustrated in table (1) show that, Calving pen not used in $95 \%$ in surveyed farm which nearly same with finding of Vasseur et al. (2010) who indicated that, Calving pens were not used in $51.3 \%$ of surveyed herds and instead, the cows calved in tie-stalls, while, away form data of USDA, (2008), who reported that, $29.9 \%$ of United States farms do not have a calving area

\subsection{Individual or group rearing:}

Our data in table (1) showed that, the single or grouped calving pen was similar in percentage as $2 \%$ or $3 \%$ respectively which disagreed with finding of Vasseur et al. (2010) who find that, unweaned calves individually housed reperesent $87.9 \%$ of surveyed farms.

One of the most contentious calf welfare issues is the use of individual housing. (Rushen et al., 2008). The claimed advantages of individual housing are reduced transmission of diseases.

\subsection{Disinfections used}

In $67 \%$ of herds surveyed, the disinfection of the newborn's navel was not done which disagreed with recommendations and finding of (National Farm Animal Care Council, 2009). Who find, in $36.8 \%$ of herds surveyed, the disinfection of the newborn's navel was not done despite recommendations. The early disinfection accelerates drying up of the umbilicus to reduce infections so that calf morbidity (respiratory and enteric diseases) and mortality are decreased (Quigley et al., 1996) and the failures in treating the navel can generate infection and hernias, cause omphalitis and myiasis, while also allowing pathogenic microorganisms to

\section{5- Weaning age and type}

Weaning and separation between a cow and her calf imposes stress on both which may lead to decrease rumination after separation occurs (Lidfors, 1996). So that, weaning should be managed to avoid decreased nutrient intake and weight loss as well as frequent vocalization, which is a sign of weaning distress. (Weary et al., 2008) and Weaning should be gradual and based on the calf's ability to eat solid food. In commercial conditions, dairy calves are normally weaned at much younger ages than in the wild, which is around 6 month. (Phillips, 2001).

Our obtained data showed that $75 \%$ from owners used gradual weaning and age of weaning as $2-4$ month was $22 \%$ which agreed with (USDA, 2008) who find that, gradual weaning was used by $89.6 \%$ of farm which done by progressively reducing the quantity of milk or substitute. However, $16.5 \%$ used abrupt weaning and the median age at weaning was 7 week. Beside that, delayed separation (after $14 \mathrm{~d}$ ) induces better weight gain and better calf health and influences the development of the calf's social behavior compared with separation at $1 \mathrm{~d}$ (Flower and Weary, 2001)

\section{6- Mortality percentage}

Data illustrated in table (1) show that, the percentage of newly born animals dies within 3 month was very high $(20 \%)$ this data may be related to some reason as:

1. Grouped calving pen $(3 \%)$ which may associated with diarrhea (Frank and Kaneene, 1993), respiratory problems (Svensson et al., 2003) and the risk of Salmonella infections (Losinger et al., 1995) is lower when calving occurs in individual calving pens compared with in group settings.

2. High percentage of normal parturition $94 \%$ with only two visits per day $61 \%$ so the level of supervision may be unsuitable for cows at parturition because most parturition occur during the night, (von Keyserlingk and Weary, 2007) and the regular surveillance of cows about to calve is necessary to ensure assistance at calving when difficulties occur, to reduce perinatal mortality (Mee, 2004). 
3. Apart of colostrum was taking and spreading by $18 \%$ of owners to neighbor which may lead to increase the rate of mortality due to calves fed $3.8 \mathrm{~L}$ of colostrum in 1 or 2 feedings were equally effective in providing passive immunity. (Hopkins and Quigley, 1997) and calves provided with 2 colostrum feedings of $2 \mathrm{~L}$ at 0 and $12 \mathrm{~h}$ had higher IgG1than calves fed4L at birth. (Jaster, 2005), and to ensure that the calf receives its first colostrum feeding no more than $6 \mathrm{~h}$ after birth Animal (National Farm Care Council, 2009) positive effects based on the interaction between the cow and her calf during the first hours of life of the newborn (Toledo et al., 2007) suggesting that $60 \%$ of newborns may consume colostrum in an uncontrolled manner. In these situations, the colostrum intake in an acceptable amount and time can be reduced since the newborn vigor, concentration of immunoglobulin correlations with intake (Franklin et al., 2003).

\section{CONCLUSIONS}

The majority of government of persons were making a good effort to quickly feed all colostrum and weaned the calve more than 4 month While, on the other hand, the majority of producers don't had calving pen or used disinfectant after birth which had resulted in increase the newly born calves mortality rate and decreasing its well-being.

\section{REFERENCES}

ALgers, B. and Berg, C. (2001): Monitoring Animal Welfare on Commercial Broiler Farms in Sweden. Acta Agriculturae Scandinavica, Section A. Animal Science Supplementum 39:8092.

Cook, N.B.; Bennett, T.B. and Nordlund, $K . V$. (2004): Effect of free stall surface on daily activity patterns in dairy cows with relevance to lameness prevalence. J. Dairy Sci. 87: 2912-2922.
De Paula Vieira, A.; Von Keyserlingk, M.A.G. and Weary, D.M. (2010): Effects of pair versus single housing on performance and behavior of dairy calves before and after weaning from milk. Journal Dairy Science 93: 30793085.

Duve, LR.; Weary, DM.; Halekoh, U. and Jensen, MB. (2012): The effects of social contact and milk allowance on responses to handling, play, and social behavior

Espejo, L.A. and Endres, M.I. (2007): Herd level risk factors for lameness in highproducing cows housed in freestall barns. J. Dairy Sci. 90: 306-314.

Flower, FC. and Weary, DM. (2001): Effects of early separation on the dairy cow and calf: 2. Separation at 1 day and 2 weeks after birth. Appl Anim Behav Sci70: 275-284.

Frank, N.A. and Kaneene, J.N. (1993): Management risk factors associated with calf diarrhea in Michigan dairy herds. J. Dairy Sci. 76: 1313-1323.

Franklin, S.T.; Amaral-Phillips, D.M.; Jackson, J.A. and Campbell, (2003): Health and performance of Holstein calves that suckled or were hand-fed colostrum and were fed one of three physical forms of starter. Journal Dairy Science 86: 2145-2153.

Franklin, S.T.; Amaral-Phillips, D.M.; Jackson, J.A. and Campbell, A.A. (2003): Health and performance of Holstein calves that suckled or were hand-fed colostrum and were fed one of three physical forms of starter. Journal Dairy Science 86: 2145-2153.

Fulwider WK.; Grandin T.; Rollin BE.; Engle TE. and Dalsted NL. (2008): Survey of dairy management practices on one hundred thirteen north central and northeastern United States dairies. J Dairy Sci 91: 1686-1692.

Fulwider, W.K.; Grandin, T.; Garrick, D.J.; Engle, T.E.; Lamm, W.D.; Dalsted, N.L. and Rollin, B.E. (2007): Influence of free-stall base on tarsal joint lesions and hygiene in dairy cows. J. Dairy Sci. 90: 3559-3566. 
Fulwider, WK.; Grandin, T.; Rollin, BE.; Engle, TE. and Dalsted, NL. (2008): Survey of dairy management practices on one hundred thirteen north central and northeastern United States dairies. J Dairy Sci 91:1686-1692.

Hopkins, B.A. and Quigley III, J.D. (1997): Effects of method of colostrum feeding and colostrum supplementation on concentrations of immunoglobulin $G$ in the serum of neonatal calves. J. Dairy Sci. 80: 979983. in young dairy calves. J Dairy Sci 95: 6571-6581.

Jaster, E.H. (2005): Evaluation of quality, quantity, and timing of colostrum feeding on immunoglobulin G1 absorption in Jersey calves. J. Dairy Sci. 88: 296-302.

Kehoe, SI.; Jayarao, BM. and Heinrichs, AJ. (2007): A survey of bovine colostrum composition and colostrum management practices on Pennsylvania dairy farms. J Dairy Sci 90: 4108-4116

Kertz, A.; Reutzel, L.; Mahoney, J. (1984): Ad libitum water intake by neonatal calves and its relationship to calf starter intake, weight gain, feces score, and season. J Dairy Sci 1984; 67: 2964-2969.

Lidfors, LM. (1996): Behavioural effects of separating the dairy calf immediately or 4 days post-partum. Appl Anim Behav Sci 49: 269-283.

Losinger, W.C. and Heinrichs, A.J. (1995): Dairy operation management practices and herd milk production. Journal Dairy Science 79: 506-514.

Mee, J.F. (2004): Managing the dairy cow at calving time. Vet. Clin. Food Anim. 20:521-546.

National Farm Animal Care Council (NFACC). (2009): Code of Practice for the Care and Handling of Dairy Cattle. Dairy Farmers of Canada, Ottawa, ON, Canada

Phillips, C.J.C. (2001): Feeding Method. Principles of Cattle Production. CABI Publishing, Wallingford, UK.
Quigley III, J.D.; Nyabadza, C.S.T.; Benedictus, G. and Brand, A. (1996): Monitoring replacement rearing: Objectives and materials and methods. Pages 75-102 in Herd Health and Production Management in Dairy Practice.

Rushen J.; De Passille' AMB.; Von Keyserlingk MAG. and Weary DM (2008): The welfare of cattle; Phillips C, editor. Dordrecht, Netherlands: Springer. $310 \mathrm{p}$.

Rushen, J.; De Passillé, AMB.; Von Keyserlingk, MAG. and Weary, DM. (2008): The welfare of cattle; Phillips C, editor. Dordrecht, Netherlands: Springer. $310 \mathrm{p}$.

Schreiner, D.A. and Ruegg, P.L. (2002): Effects of tail docking on milk quality and cow cleanliness. J. Dairy Sci. 85: 2503-2511.

Svensson, C.; Lundborg, K.; Emanuelson, $U$. and Olsson, S.O. (2003): Morbidity in Swedish dairy calves from birth to 90 days of age and individual calf-level risk factors for infectious diseases. Prev. Vet. Med. 58:179-197.

Toledo, L.M.; Paranhos Da Costa, M.J.R.; Titto, E.A.L.; Figueiredo, L.A. and Ablas, D.S. (2007): Impactos de variáveis climáticas na agilidade de bezerros Nelore neonatos. Ciência Rural 37:1399-1404.

USDA (2008): Part III: Reference of dairy cattle health and management practices in the United States, 2007. Fort Collins, CO: United States Department of Agriculture.

Vasseur, E.; Borderas, F.; Cue, R. I.; Lefebvre, D.; Pellerin, D.; Rushen, J.; Wade, K.M. and De Passillé, A.M. (2010): A survey of dairy calf management practices in Canada that affect animal welfare. Journal Dairy Science 93:1307-1315.

Vasseur, E.; Borderas, F.; Cuе, RI.; Lefebvre, D. and Pellerin, D. (2010): A survey of dairy calf management practices in Canada that affect animal welfare. J Dairy Sci 93: 1307-1315. 
Von Keyserlingk, M.A.G., and Weary, D.M. (2007): Maternal behavior in cattle. Horm. Behav. 52:106- 113.

Weary, D.M.; Jasper, J. and Hetzel. M. (2008): Understanding weaning distress. Appl. Anim. Behav. Sci. 110:24-41.
Weaver, D.M., Tyler, J.W.; VanMetre, D.C.; Hostetler, D.E. and Barrington, G.M. (2000): Passive transfer of colostral immunoglobulins in calves. J. Vet. Intern. Med. 14: 569-577.

\section{دراسة استقصائية (استبيان) للممارسات الإدارية للعجول حليثى الولادة في محافظه الوادي الجديا}

نورا عبل الباعث سبي ، معتز /حد محد ، سطوحى /حد سطوحى، رمضان دربير محد

E-mail: norabaeth@gmail.com Assiut University web-site: www.aun.edu.eg

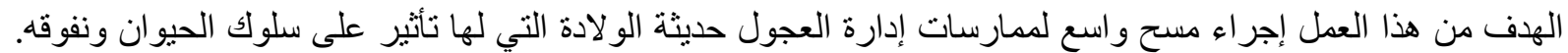

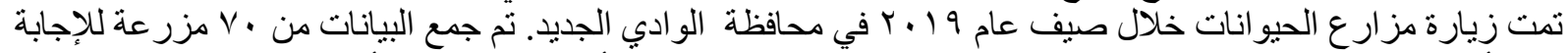

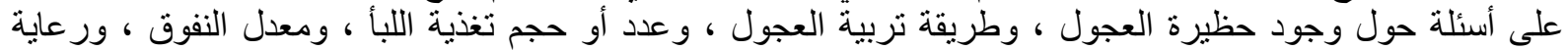
الحيو ان حديث الو لادة ، و عمر الفطام و الطريقة المستخدمة.

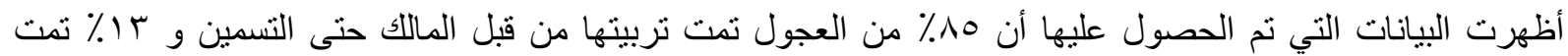

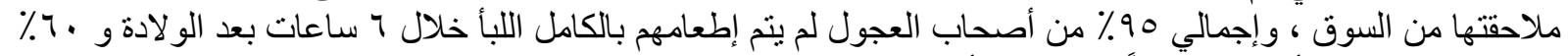

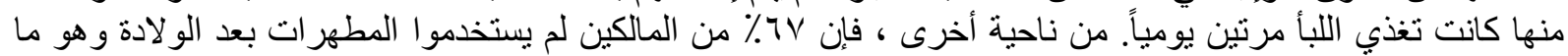

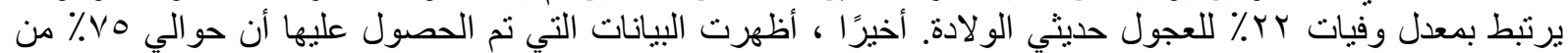

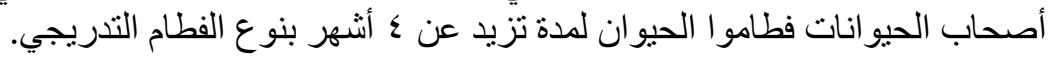
الكلمات المفتاحية: إدارة العجول حديثاً ، طريقة الفطام ، تربية العجول. 